\title{
Agronomic Use of Slurry from Anaerobic Digestion of Agroindustrial Residues: Effects on Crop and Soil
}

\author{
Amabelia del Pino1, Omar Casanova1, Mónica Barbazán'1, Victoria Mancassola1, \\ Laura Arló1, Liliana Borzacconi², Mauricio Passeggi2 \\ ${ }^{1}$ Departamento de Suelos y Aguas, Facultad de Agronomía, Universidad de la República, Montevideo, Uruguay \\ ${ }^{2}$ Departamento de Ingeniería de Reactores, Facultad de Ingeniería, Universidad de la República, \\ Montevideo, Uruguay \\ Email: amabelia@fagro.edu.uy
}

Received 10 January 2014; revised 9 February 2014; accepted 5 March 2014

Copyright (C) 2014 by authors and Scientific Research Publishing Inc.

This work is licensed under the Creative Commons Attribution International License (CC BY).

http://creativecommons.org/licenses/by/4.0/

\section{(c) (i) Open Access}

\section{Abstract}

In a greenhouse experiment we evaluated the application of slurry generated by a biogas reactor of agroindustrial residues. The objectives of this study were to determine the response to slurry application on dry matter production and nutrients absorption of Setaria italica (setaria), and to evaluate the effect of the slurry on soil properties. Two soils, of different texture, were mixed either with slurry or with diammonium phosphate (DAP) at 0,80 , and $160 \mathrm{~kg} \mathrm{~N} \mathrm{ha}^{-1}$ equivalent rates. The setaria was harvested 68 days after planting, and separated into leaves plus stems, ears, and roots. Total biomass and content of $\mathrm{N}, \mathrm{P}, \mathrm{K}, \mathrm{Ca}, \mathrm{Mg}, \mathrm{Cu}, \mathrm{Fe}, \mathrm{Mn}$, and $\mathrm{Zn}$ were determined in each fraction. In the soil we determined $\mathrm{pH}$, electric conductivity (EC), organic $\mathrm{C}$, available $\mathrm{P}$, mineral $\mathrm{N}$, and exchangeable cations. Although the biomass produced and the amounts of nutrients absorbed were different in the two soils, in both of them setaria responded to the slurry application. The amounts of $\mathrm{N}$ absorbed from slurry and DAP were similar, indicating that the $\mathrm{N}$ from the slurry was readily available. The slurry application also increased the absorption of other macro and micro nutrients ( $\mathrm{P}, \mathrm{Ca}, \mathrm{Mg}$, and $\mathrm{Zn}$ ). No significant changes in soil exchangeable cations, $\mathrm{pH}$, and EC were observed at setaria harvest. In the silty soil the crop almost depleted the mineral $\mathrm{N}$ in all treatments, but in the sandy soil large amounts were left, especially in the treatments with slurry. This fact highlights the importance of a careful dosage of this soil amendment, to avoid the excess of mineral $\mathrm{N}$, which is potential pollutant for the environment. It can be concluded that the use of slurry from the reactor had a positive effect on the nutrients availability, without negative effects on soil properties.

\section{Keywords}

Biosolids; Biogas Slurry; Setaria Italica; Uruguay 


\section{Introduction}

The Uruguayan economy is mainly based on agriculture, with a wide range of industrial transformation of the products. These agroindustrial activities produce different types of residues or by-products, which are difficult and expensive to dispose.

Fruit and vegetable production in Uruguay is concentrated in the south of the country from which the capital is supplied. Also meat and dairy industries are mainly located in the area. This agro-industrial development generates approximately 130,000 tons of residues each year. To date most of the final disposal of the agroindustrial residues is made without any treatment, but the normative is increasingly restrictive in this aspect.

The intensive land use has led to soil degradation and nutrient depletion in most of the area. To maintain soil productivity in these highly extractive systems the addition of fertilizers is not sufficient, therefore the amendment of the soils with organic materials, to replenish the lost soil organic matter (SOM), and nutrients, has been recommended [1].

The majority of these waste materials are rich in C, and therefore suitable for energy production. In this context the anaerobic treatment has many advantages, such as energy production, soil amendment with the stabilized slurry, and the possibility to trade C credits [2] [3].

The characteristics of the biogas slurry depend on the waste used in the reactor, therefore its value for plant nutrition will be closely related to the combination of agroindustrial residues used [4]. In dairy production systems in Uruguay the biogas production from cow manure has been developed to some extent, generating nutrient-rich slurry. In an evaluation of the slurry produced by these systems, [5] reported increases in yield, and higher nutrient extraction of extensive crops that received biogas slurry applications. Reference [6] also reported positive effects of biogas slurry in crops, with increases in SOM content and microbial activity. However, the slurry from the anaerobic digestion of residues as a source of organic $\mathrm{C}$ and nutrients has not been extensively used, although the organic amendment for intensive production is widely adopted [7]. Additionally the anaerobic treatment can be a mean to decontaminate the materials from pathogens and other pollutants, which represent a threat for vegetable and fruit production.

Our objectives were to determine the response to biogas slurry application on the biomass production, and nutrients absorption of Setaria italica (setaria), and to evaluate the effects of the slurry on soil properties.

\section{Materials and Methods}

For the experiment we collected soil from the superficial layer $(0-15 \mathrm{~cm})$ of two different sites (Table 1$)$. Soil 1 was a silty soil from an intensive production farm, while Soil 2 was a sandy soil under native pasture. For simplicity, the soils will be referred as S1 and S2.

\begin{tabular}{ccc} 
Table 1. Selected soil characteristics $(0-15 \mathrm{~cm})$ & \\
\hline & Soil 1 (S1) & Soil 2 (S2) \\
\hline Sand $\left(\mathrm{g} \cdot \mathrm{kg}^{-1}\right)$ & 288 & 675 \\
Silt $\left(\mathrm{g} \cdot \mathrm{kg}^{-1}\right)$ & 581 & 182 \\
Clay $\left(\mathrm{g} \cdot \mathrm{kg}^{-1}\right)$ & 131 & 143 \\
$\mathrm{pH}\left(\mathrm{H}_{2} \mathrm{O}\right)$ & 5.8 & 6.2 \\
Organic C $\left(\mathrm{g} \cdot \mathrm{kg}^{-1}\right)$ & 10.1 & 17.2 \\
P Bray-1 $\left(\mathrm{mg}^{-1} \mathrm{~kg}^{-1}\right)$ & 64.0 & 2.2 \\
Exchangeable cation & & \\
Ca $\left(\mathrm{cmol}_{\mathrm{c}} \cdot \mathrm{kg}^{-1}\right)$ & 6.21 & 11.61 \\
$\mathrm{Mg}\left(\mathrm{cmol}_{\mathrm{c}} \cdot \mathrm{kg}^{-1}\right)$ & 1.96 & 1.93 \\
$\mathrm{~K}\left(\mathrm{cmol}_{\mathrm{c}} \cdot \mathrm{kg}^{-1}\right)$ & 0.75 & 0.24 \\
$\mathrm{Na}\left(\mathrm{cmol}_{\mathrm{c}} \cdot \mathrm{kg}^{-1}\right)$ & 0.85 & 0.94 \\
\hline
\end{tabular}


The slurry utilized was produced during the anaerobic digestion of agroindustrial residues (Table 2). A pilot reactor ( $5 \mathrm{~m}^{3}$ capacity) was constructed, and daily supplied with the equivalent to $2.9 \mathrm{~kg} \cdot \mathrm{m}^{-3}$ volatile solids. The residues used were: rumen content from meat industry, fat from tannery industry, and slurry from a waste treatment plant, in a 4:2:1 proportion in volume (2.5:1.6:1 in dry weight). The hydraulic residence period of the digester was 30 days, and the working temperature $35^{\circ} \mathrm{C}$. During the operation the evolution of volatile solids and biogas production were monitored. The biogas composition was analyzed through gas chromatography. It is important to remark that the tannery residues were collected previous to any chemical addition.

The amendment treatments were: slurry and diammonium phosphate (DAP, $18 \% \mathrm{~N}$ and $46 \% \mathrm{P}_{2} \mathrm{O}_{5}$ ) at 80 and $160 \mathrm{~kg} \mathrm{~N} \mathrm{ha}^{-1}$ equivalent rates, plus a control without any addition. The amounts of fresh slurry corresponded to 90 and $180 \mathrm{Mg} \cdot \mathrm{ha}^{-1}$, for the 80 and $160 \mathrm{~N}$ rates, respectively, and were calculated based on the $\mathrm{N}$ content in the slurry, dry basis. The P rates of slurry corresponded to 60 and $120 \mathrm{~kg}_{\text {of }} \mathrm{P}_{2} \mathrm{O}_{5} \mathrm{ha}^{-1}$ and for DAP to 200 and 400 $\mathrm{kg}$ of $\mathrm{P}_{2} \mathrm{O}_{5}$ ha $^{-1}$ for the low and high rates respectively. The rates were calculated considering a soil depth of 15 $\mathrm{cm}$ and a bulk density of $1.25 \mathrm{~g} \cdot \mathrm{cm}^{-3}$, and are based in the usual recommendation for setaria in dairy production systems.

For the greenhouse experiment the fresh soils were passed through a $1 \mathrm{~cm}$ mesh. The amount corresponding to each pot (4 kg, dry basis) was extended in a fine layer, and the slurry and fertilizer were applied. The materials were mixed, and the amount of water to reach field capacity in each soil ( 0.25 and $0.22 \mathrm{~g} \cdot \mathrm{g}^{-1}$ for S1 and S2, respectively) was added. Ten pre-germinated seeds of setaria were sown in each pot, which were thinned two weeks later to 5 plants per pot. Three replications were prepared in S1, and two in S2. The pots were daily watered with deionized water to replenish evapotranspiration losses. Setaria was sown on January 18, 2011 and harvested at March 27, 2011. At harvest the plants were still green, although the ears were developed, indicating that they approached physiological maturity. The plants were separated into three fractions: leaves plus stem, ears, and roots.

Soil samples were collected at the harvest of setaria, dried at $40^{\circ} \mathrm{C}$ for 48 hours, and ground for analysis. The

\begin{tabular}{|c|c|c|c|}
\hline & \multirow[t]{2}{*}{ Composition } & \multicolumn{2}{|c|}{ Nutrients applied to the pot experiment } \\
\hline & & Low rate & High rate \\
\hline & $\mathrm{g} \cdot \mathrm{kg}^{-1}$ & $\mathrm{mg} \cdot \mathrm{kg}^{-1}$ & $\mathrm{mg} \cdot \mathrm{kg}^{-1}$ \\
\hline Dry matter & 44 & 2150 & 4300 \\
\hline C & 330 & 704 & 1408 \\
\hline $\mathrm{N}$ & 20.0 & 43 & 86 \\
\hline $\mathrm{P}$ & 6.4 & 14 & 28 \\
\hline $\mathrm{Ca}$ & 39.2 & 84 & 168 \\
\hline $\mathrm{Mg}$ & 8.7 & 19 & 38 \\
\hline K & 2.4 & 5 & 10 \\
\hline \multirow[t]{2}{*}{$\mathrm{Na}$} & 5.7 & 12 & 24 \\
\hline & $\mathrm{mg} \cdot \mathrm{kg}^{-1}$ & & \\
\hline $\mathrm{Cu}$ & 26 & 0.05 & 0.10 \\
\hline $\mathrm{Fe}$ & 2508 & 5 & 10 \\
\hline $\mathrm{Mn}$ & 158 & 0.32 & 0.64 \\
\hline $\mathrm{Zn}$ & 94 & 0.21 & 0.42 \\
\hline $\mathrm{pH}$ & 8.0 & & \\
\hline C:N & 16.5 & & \\
\hline
\end{tabular}


mineral $\mathrm{N}$ was extracted with $2 \mathrm{M} \mathrm{KCl}$ (soil:solution 1:10). The $\mathrm{NO}_{3}^{-}-\mathrm{N}$ and $\mathrm{NH}_{4}^{+}-\mathrm{N}$ contents in the extracts were colorimetrically determined [8] [9]. The available $\mathrm{P}$ was determined by Bray 1 method [10]. The exchangeable cations were extracted with $1 \mathrm{M}$ ammonium acetate (soil:solution 1:10). The Ca and Mg content of the extracts were determined by atomic absorption and the $\mathrm{K}$ and Na contents by atomic emission [11]. To determine $\mathrm{pH}$ and electrical conductivity (EC) the soil:water relationship was 1:2.5.

The biosolid and plant samples were dried at $65^{\circ} \mathrm{C}$ for $48-72$ hours (until constant weight) and ground to pass a $0.5 \mathrm{~mm}$ screen. The $\mathrm{N}$ content was analyzed by Kjeldahl distillation after digestion with concentrated $\mathrm{H}_{2} \mathrm{SO}_{4}$. For $\mathrm{P}$ and cation analysis the samples were ignited at $550^{\circ} \mathrm{C}$ for 5 hours, and dissolved with $\mathrm{HCl}$. Phosphorus was determined according to [12], $\mathrm{Ca}, \mathrm{Mg}, \mathrm{Fe}, \mathrm{Cu}, \mathrm{Zn}$, and $\mathrm{Mn}$ by atomic absorption, $\mathrm{K}$ and $\mathrm{Na}$ by atomic emission [11]. To determine the $C$ content of the slurry a wet oxidation procedure with $\mathrm{K}_{2} \mathrm{Cr}_{2} \mathrm{O}_{7}$ was used [13].

For the statistical analysis a completely randomized design was used separately for each soil. Differences between the effects of slurry and synthetic fertilizer were tested through contrast analysis.

\section{Results and Discussion}

The S1 site presented erosion symptoms, and the superficial layer had probably lost a great proportion of the original SOM, due to the long agricultural use. In contrast the S2 site was under native pasture, with high SOM content. The level of available $\mathrm{P}$ could be also related to the site history, with high values in S1, due to frequent P fertilizer applications, while the low content in S2 is characteristic of unfertilized soils in Uruguay. Given these characteristics of the sites, the most likely limiting nutrient would be N in S1 and P in S2.

The materials digested in the reactor, especially rumen content, determined that the resulting slurry presented high $\mathrm{C}, \mathrm{N}$, and $\mathrm{P}$ contents. The low $\mathrm{C}: \mathrm{N}$, ratio suggests that the material was easily decomposable, in agreement with other studies [14]. The high Ca content was probably inherited from the original materials, and the K content was rather poor. Regarding to $\mathrm{Na}$, which in excess would produce a negative effect in the soil, the estimated amount added with the slurry was approximately 0.05 and $0.10 \mathrm{cmol}_{\mathrm{c}} \cdot \mathrm{kg}^{-1}$ of soil for the 80 and $160 \mathrm{~N}$ rates, respectively. Although these values are not considered a threat, frequent applications of slurries could increase the exchangeable $\mathrm{Na}$ in the soil, producing clay dispersion, and negatively affecting the soil structure and permeability. The contents of Fe, Mn, Zn, and Cu in the slurry were within the ranges cited by [7] in a survey of the different organic materials used in Uruguay for soil amendment. These results were also similar to those presented by [15] in a survey of animal manures in UK. These characteristics were expected, because it is accepted that the biogas slurry is highly influenced by the characteristics of the reactor inputs [4]. In our study the materials used for biogas production did not suffer any process with addition of chemicals, therefore they presented similar contents of $\mathrm{Fe}, \mathrm{Mn}, \mathrm{Zn}$, and $\mathrm{Cu}$ as other organic amendments.

In a previous laboratory experiment, we studied the decomposition patterns and nutrient release of the biogas slurry [16]. In the controlled conditions of the incubation (temperature $25^{\circ} \mathrm{C}$ and soil water content at field capacity) the slurry showed a rapid mineralization, with high $\mathrm{CO}_{2}$ and mineral $\mathrm{N}$ release. The increase in microbial biomass activity produced by the slurry addition has been reported in many studies [17] [18]. In these studies the contribution of the microbial biomass has been linked to increases in nutrient availability, not only related to the slurry decomposition, but also to priming effects, resulting in native SOM mineralization [19].

\subsection{Biomass Production}

The biomass production of setaria showed a significant response $(\mathrm{P}<0.05)$ to slurry and fertilizer application in both soils (Figure 1). In S1 the production with slurry was higher than DAP $(\mathrm{P}<0.05)$, but there were not differences between application rates within each material. This result suggests that the benefit of the slurry can be explained not only by the $\mathrm{N}$ and $\mathrm{P}$ supply, but also by other reasons.

One of the possible positive effects of the slurry is the improvement of physical properties, increasing gaseous exchange and therefore a higher root biomass and soil exploration [20]. Although no significant differences were found, in our study the root:shoot ratios of the slurry treatments ( 0.27 and 0.24 for low and high slurry rate, respectively) were higher than those of the Control and DAP treatments $(0.19,0.17$, and 0.19 for the Control, Low, and High DAP rate, respectively).

In S2 there were no significant differences in biomass production among the Control and the Low rate of either slurry or DAP, but the High rate of both sources produced higher yields $(\mathrm{P}<0.05)$. In this soil the 
root:shoot ratio was higher than in S1 for all treatments, especially in the Control (1.17, data not shown), which was significantly larger than the others ( 0.46 for the average of slurry and DAP). This result is probably related to the extremely low $\mathrm{P}$ availability of this soil, since it has been reported that the P starvation induces preferential allocation of biomass to roots [21].

\subsection{Nutrient Absorption}

The addition of slurry and fertilizer produced significant effects on the $\mathrm{N}$ concentration in shoots, ears, and roots of the setaria (Table 3).

In S1 there was an increase in $\mathrm{N}$ absorption with the slurry application, similar to the effect of the fertilizer application. These results indicate that the availability was similar in both sources. However, it should be remembered that the experiment was conducted during summer, with high temperature and humidity, ideal conditions for slurry decomposition. In S2 there were no differences in $\mathrm{N}$ concentration among treatments, and the values were generally higher than those of S1, which was probably due to the higher capacity for $\mathrm{N}$ supply of this soil.

There was also a different effect of the soil type on the plant $\mathrm{P}$ contents, with higher $\mathrm{P}$ concentrations in all plant fractions in S1, which are in agreement with the high $\mathrm{P}$ availability of the soil at the beginning of the experiment. In this soil the plants with slurry and fertilizer showed significantly higher concentrations than the Control, but the effect of the higher P rate of DAP was noticeable only in shoot concentrations.

In contrast in S2 there was a stronger effect of the soluble fertilizer than the slurry $(\mathrm{P}<0.05)$, reflecting the higher rate applied, and probably a more readily availability of the added P in DAP. The P concentration in forage is relevant for animal nutrition; in consequence it is possible that in S2 the treatments with slurry were below the required P levels [22]. To recommend the slurry application based in the $\mathrm{N}$ content in a deficient $\mathrm{P}$ soils like S2, the added P is unlikely to be sufficient for high quality forage, and a complementary P fertilizer application would be needed.

The amount extracted of different macro and micronutrients by the whole setaria plants (including shoots, ears, and roots) are presented in Table 4. These values are the result of many factors, such as: the soil characteristics, the nutrient supply of the slurry and fertilizer, the climatic conditions for plant growth, and the root biomass and absorption capacity of the different treatments. In both soils the high rates of slurry and DAP presented also the highest nutrient absorption.

In both soils the amounts of $\mathrm{Ca}, \mathrm{Mg}, \mathrm{K}$, and $\mathrm{Na}$ absorbed by setaria in the treatments with slurry were significantly higher than those of the DAP treatments. The absorption of cations depends in a great degree on root
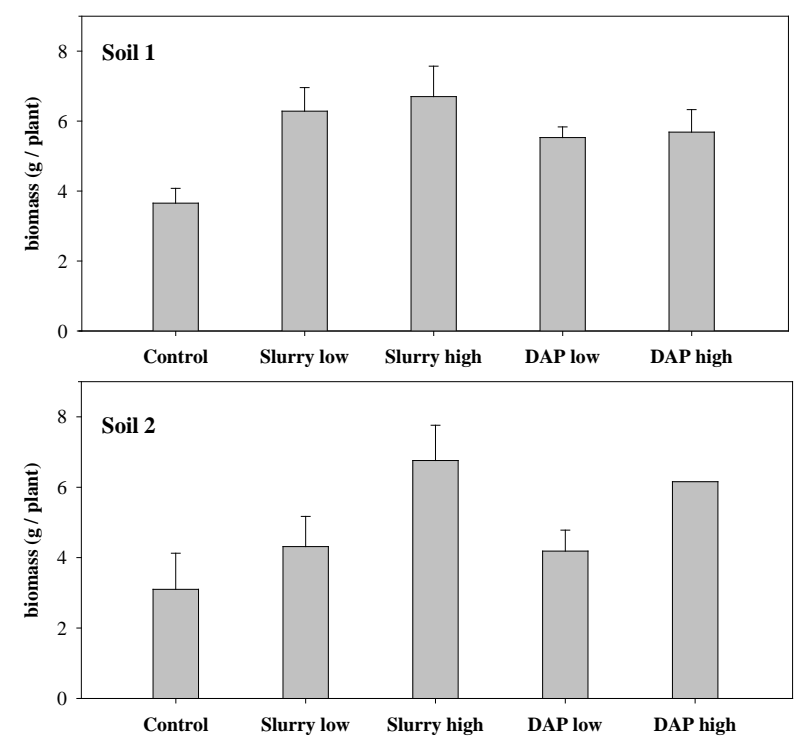

Figure 1. Biomass production of setaria in two soils with biogas slurry and fertilizer (DAP) addition. The bars indicate standard deviation of the mean. 
Table 3. Concentration of $\mathrm{N}$ and $\mathrm{P}$ in setaria and probability of the contrast analysis. In each soil and plant fraction different letters indicate significant differences $(\mathrm{P}<0.05)$ among treatments.

\begin{tabular}{|c|c|c|c|c|c|c|}
\hline \multirow{3}{*}{ Soil 1} & \multicolumn{3}{|c|}{ Nitrogen concentration } & \multicolumn{3}{|c|}{ Phosphorus concentration } \\
\hline & shoot & ear & root & shoot & ear & root \\
\hline & \multicolumn{6}{|c|}{$\left(\mathrm{g} \cdot \mathrm{kg}^{-1}\right)$} \\
\hline Control (C) & $3.4 \mathrm{c}$ & $11.2 \mathrm{c}$ & $4.5 \mathrm{~d}$ & $1.11 \mathrm{~d}$ & $3.07 \mathrm{~b}$ & $0.57 \mathrm{~b}$ \\
\hline Slurry Low (SL) & $9.2 \mathrm{~b}$ & $20.4 \mathrm{ab}$ & $10.4 \mathrm{bc}$ & $1.87 \mathrm{c}$ & $4.10 \mathrm{a}$ & $1.11 \mathrm{ab}$ \\
\hline Slurry High (SH) & $15.7 \mathrm{a}$ & $22.7 \mathrm{a}$ & $12.2 \mathrm{ab}$ & $2.17 \mathrm{bc}$ & $4.47 \mathrm{a}$ & $1.26 \mathrm{a}$ \\
\hline Fertilizer Low (FL) & $8.9 \mathrm{~b}$ & $19.3 \mathrm{~b}$ & $9.4 \mathrm{c}$ & $2.36 \mathrm{ab}$ & $4.10 \mathrm{a}$ & $1.03 \mathrm{ab}$ \\
\hline Fertilizer High (FH) & $16.4 \mathrm{a}$ & $22.4 \mathrm{a}$ & $12.6 \mathrm{a}$ & $2.69 \mathrm{a}$ & $4.67 \mathrm{a}$ & $1.23 \mathrm{a}$ \\
\hline Prob. C vs $(S+F)$ & $<0.01$ & $<0.01$ & $<0.01$ & $<0.01$ & 0.02 & 0.02 \\
\hline Prob. S vs F & 0.85 & 0.39 & 0.63 & $<0.01$ & 0.69 & 0.74 \\
\hline Prob. SL vs SH & $<0.01$ & 0.07 & 0.08 & 0.14 & 0.37 & 0.56 \\
\hline Prob. FL vs FH & $<0.01$ & 0.02 & $<0.01$ & 0.11 & 0.21 & 0.42 \\
\hline Soil 2 & \multicolumn{6}{|c|}{$\left(\mathrm{g} \cdot \mathrm{kg}^{-1}\right)$} \\
\hline Control (C) & $18.6 \mathrm{a}$ & $17.5 \mathrm{a}$ & $11.9 \mathrm{a}$ & $0.75 \mathrm{~b}$ & $1.86 \mathrm{c}$ & $0.30 \mathrm{c}$ \\
\hline Slurry Low (SL) & $16.4 \mathrm{a}$ & $20.5 \mathrm{a}$ & $11.6 \mathrm{a}$ & $0.78 \mathrm{~b}$ & $2.63 \mathrm{bc}$ & $0.44 \mathrm{bc}$ \\
\hline Slurry High (SH) & $17.3 \mathrm{a}$ & $20.5 \mathrm{a}$ & $13.2 \mathrm{a}$ & $1.13 \mathrm{~b}$ & $2.88 \mathrm{~b}$ & $0.75 \mathrm{~b}$ \\
\hline Fertilizer Low (FL) & $14.7 \mathrm{a}$ & $20.6 \mathrm{a}$ & 10.7 a & $1.01 \mathrm{~b}$ & $2.91 \mathrm{~b}$ & $0.72 \mathrm{~b}$ \\
\hline Fertilizer High (FH) & $19.3 \mathrm{a}$ & $24.9 \mathrm{a}$ & $13.5 \mathrm{a}$ & $2.04 \mathrm{a}$ & $4.30 \mathrm{a}$ & $1.32 \mathrm{a}$ \\
\hline Prob. C vs $(S+F)$ & 0.06 & 0.12 & 0.61 & 0.01 & 0.02 & $<0.01$ \\
\hline Prob. S vs F & 0.44 & 0.21 & 0.67 & 0.01 & 0.02 & $<0.01$ \\
\hline Prob. SL vs SH & 0.37 & 0.99 & 0.12 & 0.04 & 0.47 & 0.04 \\
\hline Prob. FL vs FH & $<0.01$ & 0.14 & 0.05 & 0.04 & 0.02 & $<0.01$ \\
\hline
\end{tabular}

exploration of the soil [23]. The results suggest that the increase in underground development produced by the slurry could be related to the higher cation absorption.

The use of setaria in dairy production not only requires high yields, but also high forage quality, in terms of nutrient contents [24]. Therefore, the positive effect of slurry increasing nutrient absorption also represents an advantage of the organic amendment. It is important to remark, however, that the differences were more noticeable in absorption of the macronutrients than micronutrients. This result is probably due to the limited supply of micronutrients made by the slurry.

\subsection{Effects on Soil Properties}

The analysis of soil mineral $\mathrm{N}$ after harvest show different behaviour of the soils (Figure 2). While in S1 the mineral $\mathrm{N}$ was almost depleted, in $\mathrm{S} 2$ high $\mathrm{N}-\mathrm{NO}_{3}^{-}$concentrations were found in the treatments with slurry and DAP.

Apart from the crop absorption, possible causes of the low mineral $\mathrm{N}$ level in $\mathrm{S} 1$ are $\mathrm{N}-\mathrm{NO}_{3}^{-}$losses, either through leaching or denitrification. However, these processes were unlikely to occur under the controlled conditions of the greenhouse, where water was not in excess. Since the $\mathrm{N}$ absorption of setaria was similar for the slurry and DAP treatments in both soils, the differences in the control treatment indicate a higher mineralization capacity in S2 than S1. It should be remembered that during the experimental period high temperatures occurred, which promote organic matter mineralization from the slurry and the soil. Moreover it has been proposed that 
Table 4. Content of N, P, K, Ca, Mg, Na, Cu, Fe, Mn, and Zn Cu in setaria plants (shoots, ears, and roots), and probability of the contrast analysis. In each soil and plant fraction different letters indicate significant differences $(\mathrm{P}<0.05)$ among treatments.

\begin{tabular}{|c|c|c|c|c|c|c|c|c|c|c|}
\hline & $\mathrm{N}$ & $\mathrm{P}$ & $\mathrm{Ca}$ & $\mathrm{Mg}$ & $\mathrm{K}$ & $\mathrm{Na}$ & $\mathrm{Cu}$ & ${ }^{+} \mathrm{Fe}$ & Mn & $\mathrm{Zn}$ \\
\hline Soil 1 & \multicolumn{10}{|c|}{$\left(\mathrm{mg} \cdot\right.$ plant $^{-1}$ ) } \\
\hline Control (C) & $17.1 \mathrm{~d}$ & $4.7 \mathrm{c}$ & $5.9 \mathrm{~d}$ & $4.9 \mathrm{~d}$ & $69.5 \mathrm{c}$ & $1.2 \mathrm{~d}$ & $0.01 \mathrm{~b}$ & $0.15 \mathrm{~b}$ & $0.10 \mathrm{c}$ & $0.20 \mathrm{a}$ \\
\hline Slurry Low (SL) & $69.6 \mathrm{c}$ & $12.9 \mathrm{~b}$ & $17.0 \mathrm{~b}$ & $16.5 \mathrm{bc}$ & $157.8 \mathrm{ab}$ & $4.4 \mathrm{bc}$ & $0.03 \mathrm{a}$ & $0.26 \mathrm{ab}$ & $0.16 \mathrm{bc}$ & $0.22 \mathrm{a}$ \\
\hline Slurry High (SH) & 106.6 a & $15.5 \mathrm{a}$ & $24.4 \mathrm{a}$ & 27.7 a & $179.2 \mathrm{a}$ & $6.3 \mathrm{a}$ & $0.03 \mathrm{a}$ & $0.38 \mathrm{a}$ & $0.16 \mathrm{bc}$ & $0.36 \mathrm{a}$ \\
\hline Fertilizer Low (FL) & $57.0 \mathrm{c}$ & $13.2 \mathrm{~b}$ & $14.2 \mathrm{c}$ & $13.3 \mathrm{c}$ & $148.4 \mathrm{~b}$ & $2.6 \mathrm{c}$ & $0.02 \mathrm{ab}$ & $0.33 \mathrm{a}$ & $0.23 \mathrm{~b}$ & $0.24 \mathrm{a}$ \\
\hline Fertilizer High (FH) & $93.2 \mathrm{~b}$ & 15.8 a & $17.2 \mathrm{~b}$ & $18.8 \mathrm{~b}$ & $169.6 \mathrm{ab}$ & $3.1 \mathrm{~b}$ & $0.01 \mathrm{~b}$ & $0.35 \mathrm{a}$ & $0.29 \mathrm{a}$ & $0.14 \mathrm{a}$ \\
\hline Prob. C vs (S + F) & $<0.01$ & $<0.01$ & $<0.01$ & $<0.01$ & $<0.01$ & $<0.01$ & 0.04 & $<0.01$ & $<0.01$ & 0.52 \\
\hline Prob. S vs F & $<0.01$ & 0.57 & $<0.01$ & $<0.01$ & 0.28 & $<0.01$ & 0.01 & 0.44 & $<0.01$ & 0.06 \\
\hline Prob. SL vs SH & $<0.01$ & 0.01 & $<0.01$ & $<0.01$ & 0.10 & 0.03 & 0.77 & 0.05 & $<0.01$ & 0.06 \\
\hline Prob. FL vs FH & $<0.01$ & 0.01 & 0.04 & 0.01 & 0.10 & 0.61 & 0.21 & 0.98 & 0.03 & 0.10 \\
\hline Soil 2 & \multicolumn{10}{|c|}{$\left(m g\right.$ plant ${ }^{-1}$ ) } \\
\hline Control (C) & $46.1 \mathrm{~b}$ & $1.6 \mathrm{~d}$ & $8.1 \mathrm{c}$ & $6.3 \mathrm{c}$ & $42.1 \mathrm{~b}$ & $1.2 \mathrm{a}$ & $0.02 \mathrm{a}$ & $0.09 \mathrm{a}$ & $0.11 \mathrm{c}$ & $0.13 \mathrm{~b}$ \\
\hline Slurry Low (SL) & $67.4 \mathrm{~b}$ & $4.0 \mathrm{~cd}$ & $16.7 \mathrm{bc}$ & $17.3 \mathrm{~b}$ & $40.6 \mathrm{~b}$ & $4.0 \mathrm{a}$ & $0.02 \mathrm{a}$ & $0.18 \mathrm{a}$ & $0.18 \mathrm{~b}$ & $0.15 b$ \\
\hline Slurry High (SH) & 108.6 a & $7.8 \mathrm{~b}$ & 32.3 a & 28.1 a & $62.0 \mathrm{a}$ & $6.5 \mathrm{a}$ & $0.04 \mathrm{a}$ & $0.29 \mathrm{a}$ & $0.34 \mathrm{a}$ & $0.49 \mathrm{a}$ \\
\hline Fertilizer Low (FL) & $58.1 \mathrm{~b}$ & $5.3 \mathrm{c}$ & $11.6 \mathrm{c}$ & $17.0 \mathrm{~b}$ & $34.7 \mathrm{~b}$ & $2.2 \mathrm{a}$ & $0.02 \mathrm{a}$ & $0.18 \mathrm{a}$ & $0.17 \mathrm{~b}$ & $0.12 \mathrm{~b}$ \\
\hline Fertilizer High (FH) & $112.3 \mathrm{a}$ & $13.3 \mathrm{a}$ & $20.2 \mathrm{~b}$ & 25.4 a & $36.7 \mathrm{~b}$ & $2.4 \mathrm{a}$ & $0.02 \mathrm{a}$ & $0.22 \mathrm{a}$ & $0.28 \mathrm{ab}$ & $0.15 \mathrm{~b}$ \\
\hline Prob. C vs (S + F) & 0.02 & $<0.01$ & $<0.01$ & $<0.01$ & 0.76 & 0.15 & 0.77 & 0.07 & 0.03 & 0.16 \\
\hline Prob. S vs F & 0.77 & 0.01 & $<0.01$ & 0.26 & 0.02 & 0.10 & 0.20 & 0.77 & 0.41 & 0.03 \\
\hline Prob. SL vs SH & 0.03 & 0.02 & $<0.01$ & $<0.01$ & 0.02 & 0.23 & 0.22 & 0.04 & 0.04 & $<0.01$ \\
\hline Prob. FL vs FH & 0.02 & $<0.01$ & 0.03 & $<0.01$ & 0.78 & 0.93 & 0.95 & 0.46 & 0.14 & 0.70 \\
\hline
\end{tabular}

${ }^{+} \mathrm{Fe}$ in roots was not included due to soil contamination.
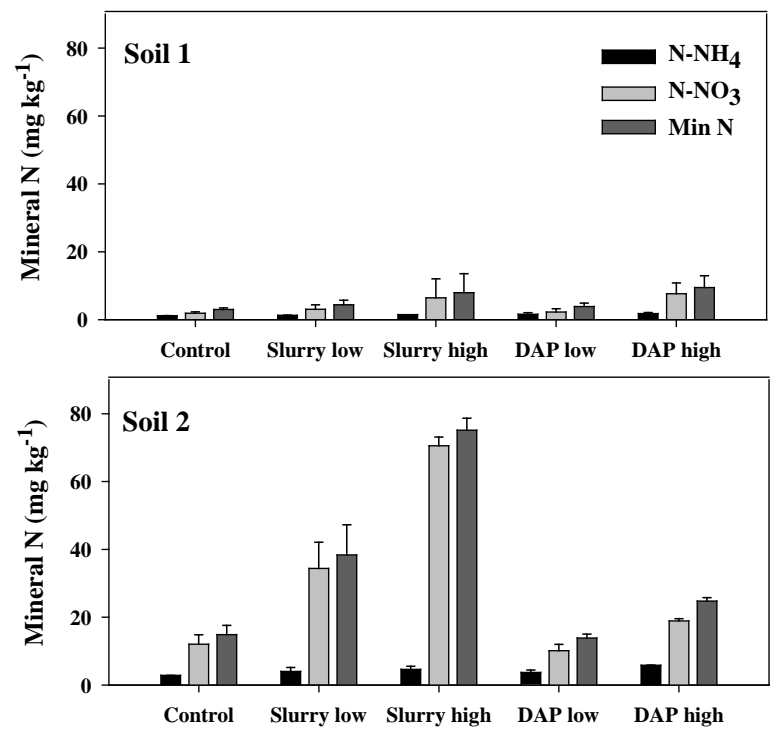

Figure 2. Soil mineral N content at harvest of setaria. Bars indicate standard deviation of the mean. 
the addition of biogas slurry could promote a priming effect, with an additional mineralization of native SOM [19]-[25]. Reference [19] cited as possible factors determining the magnitude of the priming effect the high ammonium supply, the presence of labile SOM, and plant rhizodeposition. All of these factors were likely to influence the process when slurry was added to S2.

Irrespective of the origin of the mineral $\mathrm{N}$ found in the slurry amended soil in $\mathrm{S} 2$, this fact should be taken into consideration when planning the use of slurry in the field, because the excess in mineral $\mathrm{N}$ could lead to contamination of surface or ground water, as reported by [14]. Biogas slurries present the disadvantage, like many organic amendments, that it is not possible to predict their mineralization patterns, in order to match the $\mathrm{N}$ release to the crop requirements [26].

Table 5 shows the soil properties after setaria harvest. The most important effects of the treatments in soil pH were an increase in the slurry treated soils, and a trend of lower values when DAP was applied. These results are probably due to the high $\mathrm{pH}$ of the slurries, and the soil acidification produced by ammoniacal fertilizers. The $\mathrm{CE}$ values were lower in $\mathrm{S} 1$ than in $\mathrm{S} 2$, showing the influence of the mineral $\mathrm{N}$ content (especially $\mathrm{N}-\mathrm{NO}_{3}^{-}$) on this parameter. In S2 the slurry treatments showed the highest EC, nevertheless, these EC values were below the critical levels for plant growth [27].

The available P presented wide differences between the soils, because at the beginning of the experiment S1 was well above the critical levels for most of the crops, while S2 was in the deficiency range. Therefore, the effect of the treatments on soil P availability in S1 were not relevant for the nutrition of the crop, while in S2 the addition of fertilizer or slurry, especially at high rates, were necessary to remove the P limitation. Interestingly, at the setaria harvest the available P level at S2 reached the critical level for setaria $\left(12-14 \mathrm{mg} \mathrm{kg}^{-1}\right)$ with the

Table 5. Soil pH, electric conductivity, exchangeable cation content (Ca, Mg, K, and Na), and available P after setaria harvest.

\begin{tabular}{|c|c|c|c|c|c|c|c|}
\hline & $\mathrm{pH}\left(\mathrm{H}_{2} \mathrm{O}\right)$ & EC & $\mathrm{Ca}$ & $\mathrm{Mg}$ & $\mathrm{K}$ & $\mathrm{Na}$ & P (Bray I) \\
\hline Soil 1 & & $\mathrm{dS} \cdot \mathrm{m}^{-1}$ & \multicolumn{4}{|c|}{$\mathrm{cmol}_{\mathrm{c}} \cdot \mathrm{kg}^{-1}$} & $\mathrm{mg} \cdot \mathrm{kg}^{-1}$ \\
\hline Control (C) & $6.3 \mathrm{~b}$ & $0.05 \mathrm{a}$ & $5.75 b$ & $1.78 \mathrm{a}$ & $0.47 \mathrm{a}$ & $0.57 \mathrm{a}$ & $57.7 \mathrm{c}$ \\
\hline Slurry Low (SL) & $6.3 \mathrm{~b}$ & $0.07 \mathrm{a}$ & $6.03 \mathrm{ab}$ & $1.83 \mathrm{a}$ & $0.34 \mathrm{a}$ & 0.65 a & 64.4 bc \\
\hline Slurry High (SH) & $6.6 \mathrm{a}$ & $0.11 \mathrm{a}$ & $6.26 \mathrm{a}$ & $1.87 \mathrm{a}$ & $0.34 \mathrm{a}$ & $0.67 \mathrm{a}$ & $72.3 \mathrm{bc}$ \\
\hline Fertilizer Low (FL) & $6.1 \mathrm{~b}$ & $0.07 \mathrm{a}$ & $5.97 \mathrm{ab}$ & $1.76 \mathrm{a}$ & $0.40 \mathrm{a}$ & $0.50 \mathrm{a}$ & $77.4 \mathrm{~b}$ \\
\hline Fertilizer High (FH) & $5.7 \mathrm{c}$ & 0.08 a & $6.06 \mathrm{ab}$ & 1.79 a & $0.40 \mathrm{a}$ & $0.60 \mathrm{a}$ & 115.3 a \\
\hline Prob. C vs $(\mathrm{S}+\mathrm{F})$ & 0.08 & 0.57 & 0.01 & 0.27 & 0.02 & 0.60 & $<0.01$ \\
\hline Prob. S vs F & $<0.01$ & 0.46 & 0.18 & 0.01 & 0.10 & 0.09 & $<0.01$ \\
\hline Prob. SL vs SH & $<0.01$ & 0.06 & 0.10 & 0.22 & 0.94 & 0.78 & 0.17 \\
\hline Prob. FL vs FH & $<0.01$ & 0.44 & 0.45 & 0.44 & 0.94 & 0.24 & $<0.01$ \\
\hline \multicolumn{8}{|l|}{ Soil 2} \\
\hline Control (C) & $6.2 \mathrm{a}$ & $0.13 \mathrm{c}$ & $10.96 \mathrm{a}$ & $1.94 \mathrm{ab}$ & $0.20 \mathrm{a}$ & $0.38 \mathrm{a}$ & $4.43 \mathrm{c}$ \\
\hline Slurry Low (SL) & $6.2 \mathrm{a}$ & $0.24 \mathrm{~b}$ & $10.80 \mathrm{a}$ & $1.93 \mathrm{ab}$ & $0.17 \mathrm{a}$ & $0.40 \mathrm{a}$ & $7.30 \mathrm{c}$ \\
\hline Slurry High (SH) & $6.1 \mathrm{a}$ & 0.63 a & $11.60 \mathrm{a}$ & $2.14 \mathrm{a}$ & $0.17 \mathrm{a}$ & $0.51 \mathrm{a}$ & $12.01 \mathrm{~b}$ \\
\hline Fertilizer Low (FL) & $6.1 \mathrm{a}$ & $0.12 \mathrm{c}$ & $9.84 \mathrm{a}$ & $1.67 \mathrm{~b}$ & $0.15 \mathrm{a}$ & $0.41 \mathrm{a}$ & $12.05 \mathrm{~b}$ \\
\hline Fertilizer High (FH) & $5.9 \mathrm{~b}$ & $0.18 \mathrm{bc}$ & $10.37 \mathrm{a}$ & $1.76 \mathrm{~b}$ & $0.16 \mathrm{a}$ & 0.29 a & 26.17 a \\
\hline Prob. C vs $(\mathrm{S}+\mathrm{F})$ & 0.02 & $<0.01$ & 0.65 & 0.51 & 0.03 & 0.72 & $<0.01$ \\
\hline Prob. S vs F & 0.14 & $<0.01$ & 0.14 & 0.02 & 0.25 & 0.26 & $<0.01$ \\
\hline Prob. SL vs SH & 0.14 & $<0.01$ & 0.33 & 0.14 & 0.85 & 0.29 & 0.01 \\
\hline Prob. FL vs FH & 0.02 & 0.30 & 0.57 & 0.56 & 0.56 & 0.32 & $<0.01$ \\
\hline
\end{tabular}


high, but not with the low rate of slurry. This agree with the guidelines for $\mathrm{P}$ fertilization in this region, which recommend that to increase soil test $\mathrm{P}$ in $1 \mathrm{mg} \cdot \mathrm{kg}^{-1}$, an amount of $10 \mathrm{~kg} \mathrm{P}_{2} \mathrm{O}_{5} \mathrm{ha}^{-1}$ is required in most of the soils.

Regarding to soil $\mathrm{K}$, in both soils the highest levels were observed in the Control treatment. These results suggest that the slurry application, with a very low K supply, and DAP, promoted higher growth rates, and therefore $\mathrm{K}$ extraction, lowering the soil available $\mathrm{K}$. In the Control and DAP treatments the soils presented lower $\mathrm{Na}, \mathrm{Ca}$, and $\mathrm{Mg}$ levels at harvest than in the initial sampling (Table 2), while with the high slurry rate the values were similar, indicating that the slurry was able to replenish the absorbed nutrients and these values agree with the extraction nutrient of the whole plant (Table 4).

\section{Conclusions}

The biogas slurry produced by the digestion of rumen content, fat from tannery industry, and slurry from a waste treatment plant had a positive effect in setaria growth in two soils with different nutrient limitations. The nutrient absorption, and consequently forage quality, was also enhanced by the slurry application.

When a high rate of slurry was applied in the sandy soil, a large amount of mineral $\mathrm{N}$ (mainly $\mathrm{N}-\mathrm{NO}_{3}^{-}$) still remained after setaria harvest. It is therefore recommended a careful dosage of this amendment, to avoid the $\mathrm{N}-$ $\mathrm{NO}_{3}^{-}$potential environmental pollution.

After the crop harvest no major changes were observed in soil properties in the slurry amended, compared with the Control and fertilized soils. At the agronomic rates used in this experiment, the amended soils presented higher exchangeable cations and $\mathrm{pH}$ values, which is positive for the long term crop or agricultural productivity.

\section{Acknowledgements}

The study was funded by Project FPTA 279-INIA, Uruguay.

\section{References}

[1] García de Souza, M., Alliaume, F., Mancassola, V. and Dogliotti, S. (2011) Carbono Orgánico y Propiedades Físicas del Suelo en Predios Hortícolas del Sur de Uruguay. Agrociencia Uruguay, 15, 70-81.

[2] Passeggi, M., López, I. and Borzacconi, L. (2005) Assessment of the Energy Production from Biogas in Uruguay. II Congreso de Ingeniería Química del Mercosur y IV Congreso del MERCOSUR de Ingeniería de Procesos, Brazil.

[3] López, I., Passeggi, M., Boix, C., Barcia, R., Borzacconi, L. and Lieberman, L. (2006) Generación de Lodos y Evolución de la Biomasa de un Reactor UASB a Escala Real Tratando Efluentes de Maltería. XXX Congreso Interamericano de la Asociación de Ingeniería Sanitaria (AIDIS), Uruguay.

[4] Arthuson, V. (2009) Closing the Global Energy and Nutrient Cycles through Application of Biogas Residue to Agricultural Land-Potential Benefits and Drawbacks. Energies, 2, 226-242. http://dx.doi.org/10.3390/en20200226

[5] Silva, A., Ponce de León, J., Cavassa, R. and Reyes, W. (1992) Efecto de la Aplicación de Efluentes Orgánicos de Tambo sobre la Producción de Verdeos y Propiedades Físico-Químicas del Suelo. Notas Técnicas No 16, Facultad de Agronomía, Montevideo.

[6] La Manna, A., Mieres, J., Acosta, Y. and Torres, I. (2004) Utilización de Efluentes en Tambos. Resumen de Investigación. Actividades de difusión No 361, Resultados Experimentales en Lechería, INIA, Uruguay, 35-44.

[7] Barbazán, M., del Pino, A., Moltini, C., Hernández, J. and Rodríguez, J. (2011) Caracterización de Materiales Orgánicos Aplicados en Sistemas Agrícolas Intensivos de Uruguay. Agrociencia Uruguay, 15, 82-92.

[8] Mulvaney, R.L. (1996) Nitrogen Inorganic Forms. In: Sparks, D.L., et al., Eds., Methods of Soil Analysis. Part 3. Chemical Methods, ASA and SSSA, Madison, 1123-1184.

[9] Rhine, E.D., Sims, G.H., Mulvaney, R.L. and Pratt, E.J. (1998) Improving the Berthelot Reaction for Determining Ammonium in Soil Extracts and Water. Soil Science Society of America Journal, 62, 473-480. http://dx.doi.org/10.2136/sssaj1998.03615995006200020026x

[10] Bray, R.H. and Kurtz, L.T. (1945) Determinations of Total, Organic and Available Forms of Phosphorus in Soils. Soil Science, 59, 39-45. http://dx.doi.org/10.1097/00010694-194501000-00006

[11] Isaac, R.A. and Kerber, J.D. (1971) Atomic Absorption and Flame Photometry: Techniques and Uses in Soil, Plant and Water Analysis. In: Walsh, L.M., Ed., Instrumental Methods for Analysis of Soil and Plant Tissues, SSSA, Madison, 17-37. 
[12] Murphy, J. and Riley, J.P. (1962) A Modified Single Solution Method for the Determination of Phosphate in Natural Waters. Analytica Chimica Acta, 27, 31-36. http://dx.doi.org/10.1016/S0003-2670(00)88444-5

[13] Nelson, D.W. and Sommers, L.E. (1996) Total Carbon, Organic Carbon, and Organic Matter. In: Sparks, D.L., et al., Eds., Methods of Soil Analysis. Part 3. Chemical Methods, ASA and SSSA, Madison, 961-1010.

[14] Matsunaka, T., Sawamoto, T., Ishimura, H., Takakura, K. and Takekawa, A. (2006) Efficient Use of Digested Cattle Slurry from Biogas Plant with Respect to Nitrogen Recycling in Grassland. International Congress Series, 1293, 242252. http://dx.doi.org/10.1016/j.ics.2006.03.016

[15] Nicholson, F.A., Chambers, B.J., Williams, J.R. and Unwin, R.J. (1999) Heavy Metal Contents of Livestock Feeds and Animal Manures in England and Wales. Bioresource Technology, 70, 23-31. http://dx.doi.org/10.1016/S0960-8524(99)00017-6

[16] del Pino, A., Casanova, O., Barbazán, M., Mancassola, V., Arló, L., Rodríguez, J., Borzacconi, L. and Passeggi, M. (2012) Caracterización y Evaluación de Biosólidos Producidos por Digestión Anaerobia de Residuos Agroindustriales. CI Suelo, 30, 129-136.

[17] Terhoedven-Urselmans, T., Scheller, E., Raubuch, M., Ludwig, B. and Georg Joergensen, R. (2009) $\mathrm{CO}_{2}$ Evolution and N Mineralization after Biogas Slurry Application in the Field and its Yield Effects on Spring Barley. Applied Soil Ecology, 42, 297-302. http://dx.doi.org/10.1016/j.apsoil.2009.05.012

[18] Stumpe, B., Werner, S., Jung, R., Heinze, S., Jüschke, E., Strippel, C. and Marshner, B. (2012) Organic Carbon Dynamics and Enzyme Activities in Agricultural Soils Amended with Biogas Slurry Liquid Manure and Sewage Sludge. Agricultural Science, 3, 104-113.

[19] Kuzyakov, Y., Friedel, J.K. and Stahr, K. (2000) Review of Mechanisms and Quantification of Priming Effects. Soil Biology \& Biochemistry, 32, 1485-1498. http://dx.doi.org/10.1016/j.apsoil.2009.05.012

[20] Garg, R.N., Pathak, H., Das, D.K. and Tomar, R.K. (2005) Use of Flyash and Biogas Slurry for Improving Wheat Yields and Physical Properties of Soil. Environmental Monitoring and Assessment, 107, 1-9. http://dx.doi.org/10.1007/s10661-005-2021-x

[21] Raghothama, K.G. (1999) Phosphate Acquisition. Annual Review of Plant Physiology and Plant Molecular Biology, 50, 665-693. http://dx.doi.org/10.1007/s11104-004-2005-6

[22] Ternouth, J.H. (1990) Phosphorus and Beef Production in Northern Australia. 3. Phosphorus in Cattle-A Review. Tropical Grasslands, 24, 159-169.

[23] Arienzo, M., Christen, E.W., Quayle, W. and Kumar, A. (2009) A Review of the Fate of Potassium in the Soil-Plant System after Land Application of Wastewaters. Journal of Hazardous Materials, 164, 415-422.

[24] Hemingway, R.G. and Parkins, J.J. (2001) Fertiliser Usage and the Mineral Requirements of Grazing Livestock. Proceedings 466, International Fertiliser Society, York, 1-36.

[25] Fangueiro, D., Chadwick, D., Dixon, L. and Bol, R. (2007) Quantification of Priming and $\mathrm{CO}_{2}$ Emission Sources Following the Application of Different Slurry Particle Size Fractions to Grassland Soil. Soil Biology \& Biochemistry, 39, 2608-2620. http://dx.doi.org/10.1016/j.soilbio.2007.05.012

[26] Grigatti, M., Di Girolamo, G., Chincarini, R., Ciavatta, C. and Barbanti, L. (2011) Potential Nitrogen Mineralization, Plant Utilization Efficiency and Soil $\mathrm{CO}_{2}$ Emissions Following the Addition of Anaerobic Digested Slurries. Biomass and Bioenergy, 35, 4619-4629. http://dx.doi.org/10.1016/j.biombioe.2011.09.007

[27] Smith, J.L. and Doran, J.W. (1996) Measurement and Use of pH and Electrical Conductivity for Soil Quality Analysis. In: Doran, J.W. and Jones A.J. Eds., Methods for Assessing Soil Quality, SSSA Special Publication No 49, Madison, 169-185. 